\title{
研究課題別評価書
}

1. 研究課題名

ストレス応答破綻としてのメタボリックシンドロームと動脈硬化の分子機構解明

2. 氏名

眞鍋 一郎

\section{3. 研究のねらい}

過剩なカロリー㩒取や運動不足により肥満が急増しているが、肥満は様々な生活習慣病のリス ク要因となることが知られている。特に、内臓肥満を基盤として高血圧、耐糖能異常や脂質代謝 異常を併発するメタボリックシンドロームは、動脈硬化性疾患や代謝疾患の重大なリスクとなるこ とが明らかとなっている。脂肪組織は、単に脂肪を蓄積する臓器ではなく、多様な生理活性物質 (アディポカイン)を分泌する内分泌蔵器であるり、メタボリックシンドロームに中心的な役割を果た すと考えられている。我々は、生きている脂肪組織を観察する新しい手法を開発し、肥満脂肪組 織にダイナミックな炎症変化が起こっていることを見いだした。脂肪組織の肥満で生じている変化 は、動脈硬化形成過程に見られる変化と多くの共通点をもつ慢性炎症と捉えられる。本研究では、 生活習慣病の病態メカニズムについて、(1)代謝組織における炎症の意義について解析すること、 (2)心血管細胞と代謝細胞の両 方でストレス応答を担う転写制 御機構について、転写因子 KLF5 に着目した解析を行うこと、 (3)心血管系と代謝系の両者に 共通して病態を惹起する代謝ス トレスの同定とそのシグナル機 構の解明を目指して研究を進め た。

\section{4. 研究成果 \\ 1 肥満は内臓脂肪組織の炎症 を惹起する}

脂肪組織はアディポカインと 呼ばれる多数の生理活性物質 を分泌する。内臓脂肪の肥満は、 アディポカインの分泌を変化させ、 TNF- $\alpha$ 等の炎症性サイトカイン の発現が増加する。このような 炎症性サイトカインが、遠隔臓 器に炎症を惹起し、動脈硬化や インスリン抵抗性の原因となるこ とが提唱されている。当初、脂肪 細胞が炎症性サイトカインを産 出すると考えられていたが、肥 満した脂肪組織にマクロファージ が集積することが明らかとなり、 肥満脂肪組織に炎症が生じてい ることが示唆された。しかし、組 織学的に炎症が生じているかど

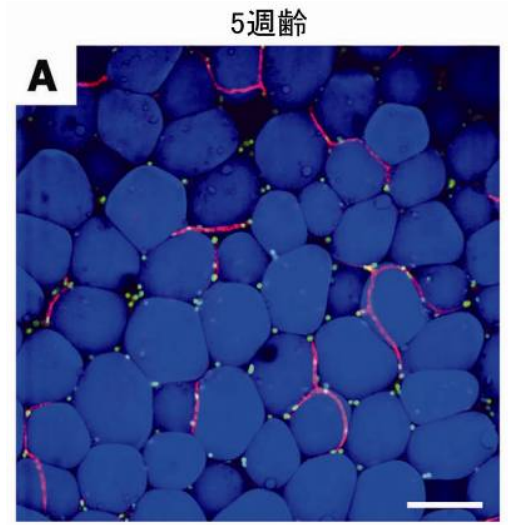

12週齢
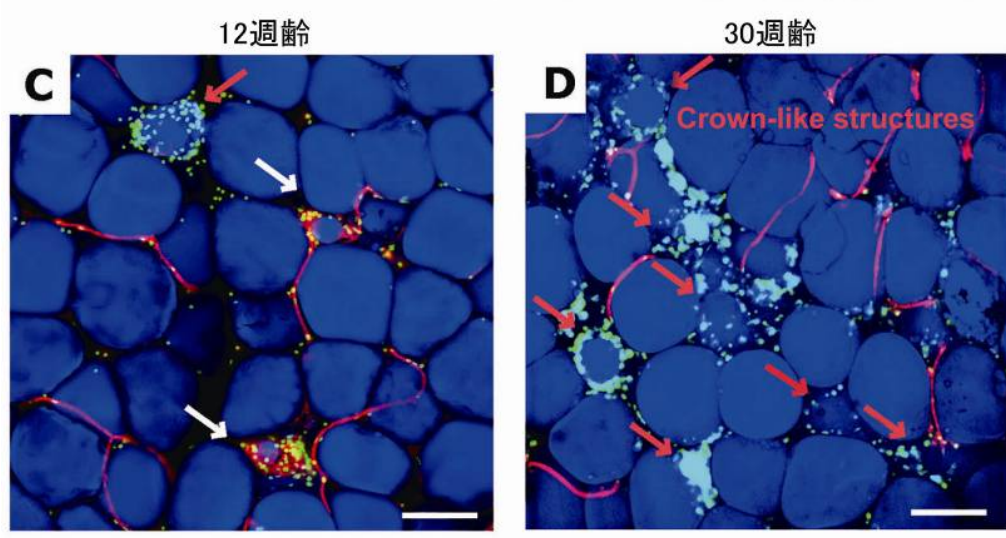

lectin BODIPY Hoechst

図 1 adipo-/angiogenic cell clusters と crown-like structures $\mathrm{db} / \mathrm{db}$ マウス精巣上体脂肪組織の肥満過程を観察すると、まず adipo-/angiogenic cell clustersにより脂肪細胞新生(組織の hyperplasia) が起こり、これに遅れて肥満が進行すると crown-like structures がみられるようになる。 
うかは明確ではなかった。炎症など の多数の細胞が関与して進む複雑な 生命現象を解析するためには、その 場所で何が起っているかを観察でき る手法が必須となる。特に、脂肪組 織は脆く、固定・切片作成の際に組 織構築を維持することが難しく、また 大きな脂肪細胞が主体であることか ら、従来の観察方法では三次元的な イメージを捉えることが難しい。そこで 我々はレーザー共焦点顕微鏡を用い て、生きている脂肪組織を未固定の まま観察できる新しいイメージング法 を開発した。この方法を用いて、内臓 脂肪組織を観察したところ、肥満過程 においてダイナミックな細胞現象が生 じていることが明らかとなった。例え

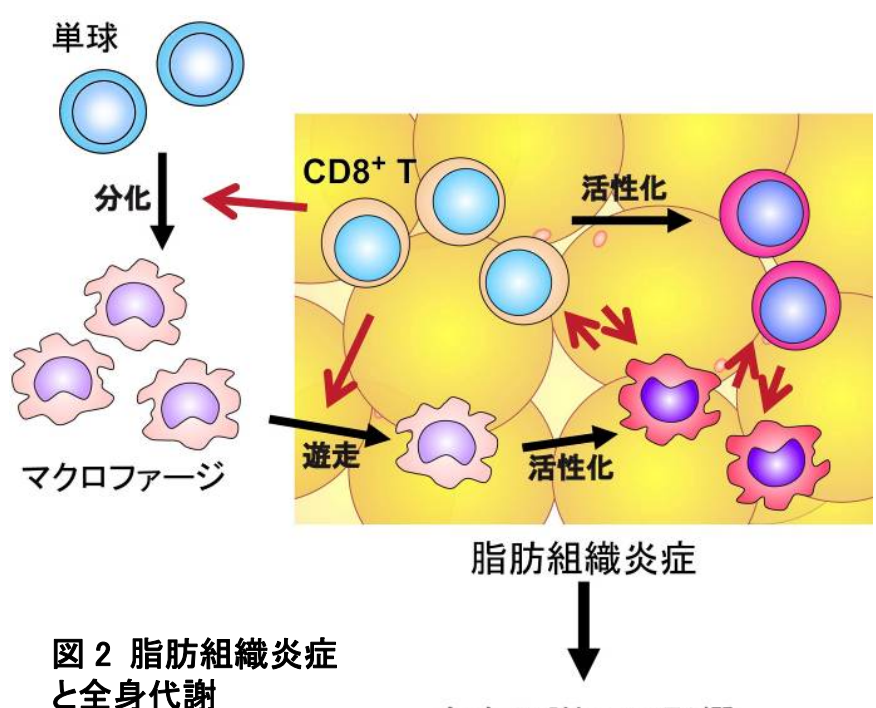

全身代謝への影響

ば、血管新生 (angiogenesis) とリンクした脂肪細胞新生 (adipogenesis) が、我々が adipo-/angiogenic cell clusters と名付けた細胞集団形成によって生じる(図 1)。また、肥満の進行 によってマクロファージが王冠状に脂肪細胞の周囲に集合する別の種類の細胞集団(Crown-like structures)が形成され、死んだ脂肪細胞をマクロファージが処理する。肥満慢性期には線維化も 認められる(Diabetes 2007)。我々はさらに脂肪組織内血管における細胞·分子現象をリアルタイ ムで観察する方法を開発した。この方法により、肥満によって血管内皮と白血球の相互作用が亢 進することが明 確になった。ま た、血流の低 下も認められ、 血管機能の変 化が脂肪組織 機能異常の原 因となっている 可能性が示唆 された ( $\mathrm{J}$ lin Invest 2008)。 これらの結果 は、肥満した脂 肪組織におい て、明確に慢 性炎症と捉え られるダイナミ ックな変化が 生じていること を明らかとし た。

$$
\text { このように肥 }
$$

満によって慢 性炎症プロセ スが惹起され ることから、次
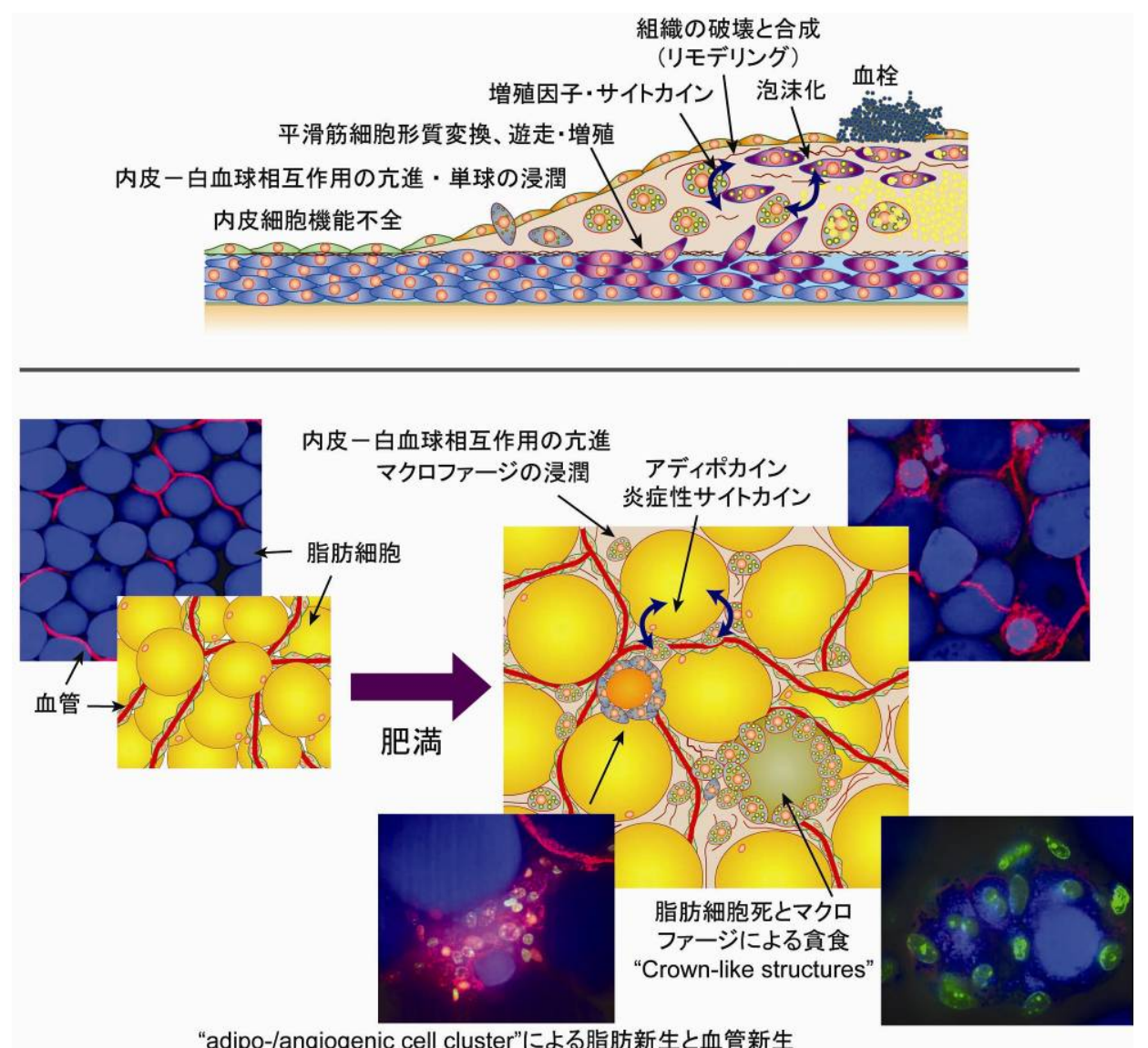

図 3 動脈硬化と脂肪組織の肥満 
に我々はその誘導メカニズムの解析を行った。高脂肪食負荷による肥満形成過程における精巣 上体脂肪組織の stromal-vascular (SV) fraction に存在する細胞種の変化をフローサイトメトリー で解析したところ、M1 マクロファージが増加する以前に effector CD8+ T 細胞が増加することを見 いだした。一方、CD4+ T 細胞や制御性 T 細胞は CD8+ T 細胞は減少する。そこで CD8+ T 細胞が 脂肪組織炎症に寄与すると考え、複数の方法で CD8+ T 細胞へのインターベンションを行った。抗 体による CD8+ T 細胞除去により、脂肪組織へのマクロファージ浸潤は抑制され、炎症性サイトカ イン発現も減少した。一方、全身のインスリン感受性は改善した。CD8a ノックアウトマウスでは、 高脂肪食により肥満は生じるものの、脂肪組織炎症は著明に抑制されていた。ここに、CD8+ T 細 胞を補充すると、脂肪組織炎症が惹起され、インスリン抵抗性も誘導された。これらの結果は、 CD8+ T 細胞が肥満脂肪組織における炎症カスケードの誘導に必須であることを示す。さらに、い つたん確立した脂肪組織肥満も、CD8+ T 細胞除去により改善することから、脂肪組織炎症の維 持にも必須であることが示された。共培養系などの検討により、CD8+ T 細胞、マクロファージ、脂 肪細胞の間に密接な相互作用があり、脂肪組織肥満において炎症カスケードを誘発·維持するこ とが示された(図 2)。このように、脂肪組織の肥満においてはダイナミックな炎症プロセスが機能 しており、全身の代謝にも多大な影響を与える。

脂肪組織の肥満に認められる現象の多くは、動脈硬化の進展過程で共通して認められる。こ のことは、代謝組織と血管の病態で多くの共通したメカニズムが機能していることを示唆する(図 3)。

\section{2 心血管疾患と代謝疾患の両者に重要な転写因子 KLF5}

我々は転写因子KLF5 を、血管病態において平滑筋細胞の形質変換を制御する転写因子とし て同定した(Nat Med 2002, Circ Res 2005)。KLF5 ヘテロノックアウトマウス(KLF5'-)の血管に傷害 を与えると、このストレスに対して形成される新生内膜がヘテロノックアウトマウスでは全く認めら れず、むしろ血管壁は菲薄化する。また、KLF5 は心肥大と線維化にも重要である。興味深いこと にKLF5ヘテロノックアウトマウスは皮下白色脂肪組織(WAT)の発達遅延を示す。この結果はKLF5 が脂肪細胞分化に必要であることを示唆する。我々はKLF5 が脂肪細胞の分化を制御する転写ネ ットワークの重要な構成因子であることを見いだした(Cell Metab 2005)。
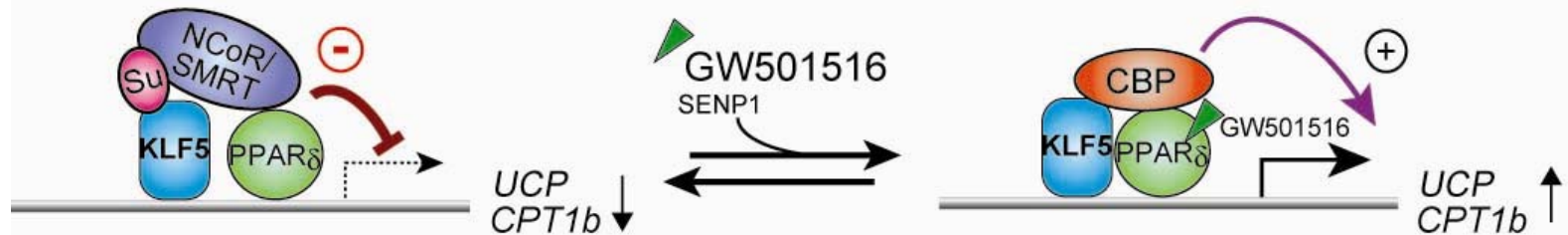

図 4 KLF5 の SUMO 化は脂肪酸燃焼関連遺伝子群発現制御の分子スイッチとして機能する

KLF5 が脂肪細胞分化に必須であることから、我々はKLF5 が成体のエネルギ一代謝制御にも関 わるのではないかと考えた。高脂肪食負荷を与えると、 $K L F 5^{+/}$マウウスでは摂餌量はむしろ六進し ているにも関わらず、体重増加は有意に抑制されることが明らかとなった。また、耐糖能やインス リン感受性も維持されており、KIF5'-は高脂肪食によるタボリックシンドロームを呈しにくいことが 分かった。KLF5 機能の詳細を解析し、KL5 が筋細胞内で脂肪酸酸化にかかわる遺伝子群の発現 を制御していることを見いだした。定常状態では、KLF5 はsmall ubiquitin-related modifier (SUMO) がKLF5 のリジン残基に結合するSUMO化を受けることによって、転写を抑制するコリプレッサーと 会合して脂肪酸燃焼に関わる遺伝子群の転写を負に制御している。ここに、PPAR $\delta$ アゴニストが 与えられると、KLF5 の脱SUMO化が生じ、SUMOが外れたKLF5 は、今度は転写を活性化するコア クチベーターと会合して、転写を正に制御することが明らかとなった。つまり、KLF5 のSUMO化は、 ちょうど転写のon/offスイッチのような機能を持つ(図 4)。このように、KLF5 は心血管疾患とメタボ リックシンドロームの両者で重要な機能を持っている(図 5)。 
3 共通した病態惹 起因子と慢性炎症 を標的とした治療 戦略

我々の解析は、 代謝臓器の病態に も慢性炎症が重要 であることを明確に 示した。慢性炎症 は、心血管系疾患 と代謝疾患の両者 で共通した基盤病 態であると考えら れる。肥満を背景 として増加する病 態因子として、 我々は遊離脂肪酸に着目し、遊離脂肪酸が血管と代謝系の両者で細胞機能異常を惹起すること を見いだした。

慢性炎症が基盤病態として重要なことから、慢性炎症プロセスに介入する新しい治療戦略が考 えられるだろう。また一方で、炎症はナノ粒子によるよい治療標的となり得る(Cancer Res 2009)。 今後さらに、ストレス応答や慢性炎症プロセスによる病態発症メカニズムを解明することによって、 新たな治療標的が同定されると考えられる。

\section{5. 自己評価}

脂肪組織の肥満で明確な炎症が生じていること、また、自然免疫系だけではなく、獲得免疫系 も重要な役割を担っていることを明確に示すことによって、慢性炎症が生活習慣病全体に重要で あることを示せたと考える。また、その分子機構についても、転写因子KLF5 が傷害ストレスと代謝 ストレスの両方に応答し、組織リモデリングとエネルギ一代謝を制御することを示すことが出来た。 今後、傷害的なストレスへの応答と代謝の調節機構のクロストークについての研究を進めること によって、生活習慣病における組織機能障害の分子機構について、新たな視点を与えることが出 来ると考える。

\section{6. 研究総括の見解}

肥満により脂肪組織にマクロファージが蓄積し、慢性炎症を引き起こすこと、即ち、肥満により 脂肪組織に動脈硬化と類似した慢性炎症が惹起されること、遊離脂肪酸が心血管系と代謝系の 両者で共通して炎症プロセスを惹起すること、さらに転写因子 KLF5 がストレス応答と代謝制御の 両方で機能すること等を明らかにした。研究は極めて順調に進められ、得られた成果は国際的に も高く評価されものである。また、レ一ザ一共焦点顕微鏡を用い、生きた脂肪組織を未固定のまま 観察する技術の開発はインパクトのある技術である。今後、新しい治療標的の同定につながるこ とが期待できる。

\section{7. 主な論文等}

A. さきがけ個人研究者主導で得られた成果で主なもの

(1)論文

1. Nishimura S, Manabe I, Nagasaki M, Seo K, Yamashita H, Hosoya Y, Ohsugi M, Tobe K, Kadowaki T, Nagai R, Sugiura S. In vivo imaging revealed local cell dynamics in obese adipose tissue inflammation. J Clin Invest 118:710-721, 2008.

2. Oishi Y, Manabe I, Tobe K, Ohsugi M, Kubota T, Fujiu K, Maemura K, Kubota N, Kadowaki T, Nagai R. SUMOylation of Krüppel-like transcription factor 5 acts as a molecular 
switch in transcriptional programs of lipid metabolism involving PPAR- $\delta$. Nat Med 14:656-666, 2008.

3. Yagi N, Manabe I, Tottori T, Ishihara A, Ogata F, Kim JH, Nishimura S, Fujiu K, Oishi Y, Itaka K, Kato Y, Yamauchi M, Nagai R. A Nanoparticle System Specifically Designed to Deliver Short Interfering RNA Inhibits Tumor Growth In vivo. Cancer Res 69:6531-6538, 2009.

4. Nishimura S, Manabe I, Nagasaki M, Eto K, Yamashita H, Ohsugi M, Otsu M, Hara K, Ueki K, Sugiura S, Yoshimura K, Kadowaki T, Nagai R. CD8+ effector T cells contribute to macrophage recruitment and adipose tissue inflammation in obesity. Nat Med 15:914-920, 2009.

5. Takeda N, Manabe I, Uchino Y, Eguchi K, Matsumoto S, Nishimura S, Shindo T, Sano M, Otsu K, Snider P, Conway SJ, Nagai R. Cardiac fibroblasts are essential for the adaptive response of the murine heart to pressure overload. J Clin Invest 120:254-265, 2010.

(2)著書

1. Nagai R, Manabe I, Suzuki T. Krüppel-like Factors: Ingenious Three Fingers Directing Biology and Pathobiology. in The Biology of Krüppel-like Factors. 3-18, 2009.

2. Manabe I, Nagai R. Drug development and Krüppel-like factors. in The Biology of Krüppel-like Factors. 245-253, 2009.

(3)招待講演

1. 真鍋一郎、血管脂肪毒性亡炎症、第 17 回日本血管生物医学会、東京、2009 年 10 月 8 日

2. 真鍋一郎、肥満と血管炎症、第 24 回日本糖尿病合併症学会 シンポジウム 3 糖尿病 血管合併症亡炎症、岡山、2009 年 10 月 9 日

3. Manabe I, Chronic inflammation is a common pathological basis of cardiovascular and metabolic diseases, 12th Cardiovascular Genomics and Atherosclerosis Symposium, Seoul, Korea $(2009 / 10 / 16)$

4. 真鍋一郎、心血管·代謝疾患の基盤病態である慢性炎症と遊離脂肪酸、第 82 回日本 生化学会大会、神戸、2009 年 10 月 22 日

5. 真鍋一郎、生活習慣病における慢性炎症プロセス、第 32 回日本分子生物学会年会、 横浜、2009年12月 11 日 